\title{
Phytotoxicity of Cardoon (Cynara cardunculus) Allelochemicals on Standard Target Species and Weeds
}

\author{
Carlos Rial, Paula Novaes, Rosa M. Varela, José M. G. Molinillo, and Francisco A. Macias* \\ Allelopathy Group, Department of Organic Chemistry, INBIO Institute of Biomolecules, Campus de Excelencia Internacional \\ Agroalimentario (ceiA3), University of Cádiz, Avda. República Saharaui, s/n, 11510 Puerto Real, Cádiz Spain
}

ABSTRACT: Cardoon (Cynara cardunculus L.) is a native plant to the Iberian Peninsula and the European Atlantic coast and invasive in American environments. Different solvents were used to perform cardoon extracts that were tested in phytotoxic bioassays. The ethyl acetate extract had the highest inhibitory activity so this was tested on the germination and growth of standard target species (lettuce, watercress, tomato, and onion) and weeds (barnyardgrass and brachiaria). The ethyl acetate extract was very active on root growth in both standard target species and weeds and it was therefore fractionated by chromatography. The spectroscopic data showed that the major compounds were sesquiterpene lactones. Aguerin B, grosheimin, and cynaropicrin were very active on etiolated wheat coleoptile, standard target species, and weed growth. The presence of these compounds explains the bioactivity of the ethyl acetate extract. The strong phytotoxicity of these compounds on important weeds shows the potential of these compounds as natural herbicide models.

KEYWORDS: allelopathy, cardoon, aguerin B, cynaropicrin, grosheimin, guaianolide, sesquiterpene lactones

\section{INTRODUCTION}

The spread of invasive plant species causes economic damage that is estimated to be up to $\$ 120$ billion dollars per year in the United States alone. ${ }^{1}$ Invasive plants have higher values of carbon, nitrogen, and water balance, leaf-area and shoot allocation, growth rate, size, and fitness (flowers, fruit, seeds, and survival) than native plants. ${ }^{2}$ Moreover, invasive plants can affect the invaded ecosystem by altering functions such as nutrient cycling, fire frequency, water availability, ${ }^{3}$ and by mechanisms such as competition and allelopathy.

Allelopathy is the influence of a plant over a target species, including plants, algae, bacteria, or fungus, through the release into the environment of compounds (allelochemicals) that influence the growth and development of biological systems. ${ }^{4}$ These compounds can be released by volatilization, root exudation, decomposition, and leaching. ${ }^{4}$ Allelopathy is recognized as an important ecological mechanism that influences the dominance and succession of plants, the formation of communities, climax vegetation, agriculture management, and productivity. ${ }^{5}$ Thus, invasive plants can introduce compounds that are new to the herbivore and plant communities. $^{6-8}$

In the case of agricultural fields, the influence of allelopathy has been demonstrated between crops and between weeds and crops. ${ }^{9}$ Allelochemicals can also be used in the development of herbicides of natural origin. ${ }^{10}$ The advantages of these herbicides are their low solubility in water, the absence of halogenated molecules, alternative modes of action, more specific interaction with weeds, lower concentrations necessary for activity, and lower levels of environmental damage. ${ }^{10}$

Cardoon (Cynara cardunculus L.) is a perennial thistle that is native to the Mediterranean region ${ }^{11}$ but has invaded American areas since its introduction in the 1800 s, where it spreads and degrades native plant communities. This plant colonizes old fields and degraded areas from which the native vegetation has been removed. ${ }^{12}$ Each cardoon plant produces between 600 and 30000 wind-dispersed seeds per year, although the plant can also have vegetative reproduction. ${ }^{13}$ Another factor that could contribute to the invasiveness of this plant is the rapid growth of the shoot and root systems, which produces higher biomass than the native species. ${ }^{14}$ White and Holt ${ }^{14}$ observed that the presence of cardoon has an adverse effect on target plants in terms of height, number of leaves, rosette diameter, as well as shoot and leaf dry weight. Allelopathy could be involved in this influence on crops and native plants.

Cardoon is used in cheese fabrication, ${ }^{15}$ but very little is known about its bioactivity. There are references in which its extracts are described as antioxidant, ${ }^{16}$ cytotoxic, ${ }^{17}$ and antimicrobial. ${ }^{18}$ However, reports have not been published to date on the allelopathy of this plant. The compounds already identified in these plants include chlorogenic acid, apigenin, ${ }^{19}$ 1,5-dicaffeoylquinic acid, ${ }^{20}$ and the saponins cynarasaponin B and cynarasaponin $\mathrm{K}^{21}$

The Poaceae species barnyardgrass (Echinochloa crus-galli L.) and brachiaria (Urochloa decumbens (Stapf) R.D. Webster) are important weed species around the world. Barnyardgrass is a weed that is native to Asia but it invades rice plantations around the world. ${ }^{22}$ Barnyardgrass is the third worst weed worldwide. It causes losses of up to $70 \%$ in rice plantations ${ }^{23}$ and can also affect other cultures such as cotton, corn, and potatoes. ${ }^{24}$ The interference of barnyardgrass with rice occurs due to its higher density, elevated macro- and micronutrient uptake and better water balance. Moreover, barnyardgrass is a host to several viruses that can be transferred to the cultures in question. ${ }^{24}$

Received: April 25, 2014

Revised: June 28, 2014

Accepted: June 29, 2014

Published: June 29, 2014 
Barnyardgrass has also developed resistance to conventional synthetic herbicides. ${ }^{22}$

Brachiaria is also especially invasive in South America. ${ }^{25}$ It is native to Africa, where it occurs in the savannas and is important in the diet of large herbivores from that continent. These plants were introduced to Brazil to serve as pasture but they have spread throughout the country. ${ }^{26}$ They are very competitive to native plants, more tolerant to fire and they can markedly modify the environment in which they dominate. ${ }^{27}$

Our hypothesis is that allelochemicals from cardoon have phytotoxic potential and could inhibit the development of other invasive weeds such as barnyardgrass and brachiaria. The aim of the study described here was to bioprospect cardoon leaf extracts through the isolation and purification of secondary metabolites with phytotoxic activity. It was envisaged that the results could explain the invasive behavior and the compounds identified could be used as natural herbicide models in the future. As part of this study, we selected the most phytotoxic extract from the leaves of cardoon, as identified by etiolated wheat coleoptile and phytotoxicity bioassays. A bioassay-guided fractionation of this extract was carried out in order to isolate and identify the chemical constituents. Their bioactivity profiles were assayed on the standard target species lettuce, watercress, tomato, and onion, as well as the weeds barnyardgrass and brachiaria.

\section{MATERIALS AND METHODS}

General Experimental Procedures. Infrared (IR) spectra ( $\mathrm{KBr}$ ) were recorded on a Fourier transform infrared (FT-IR) Spectrum 1000 spectrometer (PerkinElmer, Waltham, MA, U.S.A.). Nuclear magnetic resonance (NMR) spectra were run on 500 and $400 \mathrm{MHz}$ spectrometers (Agilent, Palo Alto, CA, U.S.A.). Chemical shifts are given in ppm with respect to residual ${ }^{1} \mathrm{H}$ signals of $\mathrm{CHCl}_{3}-\mathrm{d}_{1}(\delta 7.25)$, and ${ }^{13} \mathrm{C}$ signals are referenced to the solvent signal $(\delta 77.00)$. Optical rotations were determined at room temperature on a polarimeter model 241 (PerkinElmer, Waltham, MA, U.S.A.) (on the sodium D line). HRMS were obtained on a Synapt G2 UPLC-QTOF ESI mass spectrometer (Waters, Milford, MA, U.S.A.). HPLC was carried out on a HPLC cromatographer (Merck-Hitachi, Tokio, Japan), with RI detection. Silica gel 0.060-0.200, 60A from Acros Organics (Geel, Belgium) and Lichroprep RP $18(40-63 \mu \mathrm{m})$ from Merck (Darmstadt, Germany) were used for column chromatography. Thin layer chromatography were run on TLC Silica gel $60 \mathrm{~F}_{254}$ aluminum sheet and TLC Silica gel $60 \mathrm{RP}-18 \mathrm{~F}_{254 \mathrm{~S}}$ aluminum sheet from Merck (Darmstadt, Germany). HPLC columns used were a semipreparative column $250 \mathrm{~mm} \times 10 \mathrm{~mm}$ i.d., $10 \mu \mathrm{m}$ Lichrospher $100 \mathrm{RP}-18$ (Merck, Darmstadt, Germany) with a guard column LiChrospher RP-18 (Merck, Darmstadt, Germany) and an analytical column $250 \mathrm{~mm} \times$ $4.5 \mathrm{~mm}$ i.d., $5 \mu \mathrm{m}$ Gemini 110A RP-18 (Phenomenex, Torrance, CA, U.S.A.) with a guard column SecurityGuard Cartridges Gemini RP-18 (Phenomenex, Torrance, CA, U.S.A.).

Ultrasound extractions were performed in an ultrasonic bath (360 W, J.P. Selecta, Barcelona, Spain) in two series of $15 \mathrm{~min}$.

Chemicals. Chloroform, $n$-hexane, methanol, dichloromethane, ethyl acetate. and acetone Hipersolv Chromanorm for HPLC were obtained from VWR Internacional (Radnor, PA, U.S.A.). MagniSolv Chloroform-D1 deuteration degree min. $99.8 \%$ for NMR spectroscopy from Merck (Darmstadt, Germany).

Isolation of Compounds. Aerial plant material was collected in Jerez de la Frontera (Cadiz, Spain) in the fifth growth stage (ripe fruits).$^{28}$ Leaves were dried in an oven for $72 \mathrm{~h}$ at $40^{\circ} \mathrm{C}$ and powdered in an industrial mill. Dried material $(472 \mathrm{~g})$ with $4 \mathrm{~L}$ of $n$-hexane at room temperature (in portions of about $120 \mathrm{~g}$ of plant, $2 \times 500 \mathrm{~mL}$ ) using an ultrasonic bath in order to defat the material. The plant residue was re-extracted in two different steps.

In step one, dichloromethane, ethyl acetate, acetone, methanol, and water were used to extract defatted material $(5 \mathrm{~g}$ each, $2 \times 50 \mathrm{~mL}$ of solvent) using an ultrasonic bath and these extractions yielded, after removal of the solvent, $180 \mathrm{mg}$ (dichloromethane), $305 \mathrm{mg}$ (ethyl acetate), $449 \mathrm{mg}$ (acetone), $490 \mathrm{mg}$ (methanol), and $1643 \mathrm{mg}$ (water). These extracts were bioassayed with etiolated wheat coleoptiles. The ethyl acetate extract was the most active.

In step two, the rest of the defatted material $(418 \mathrm{~g})$ was extracted with $6 \mathrm{~L}$ of ethyl acetate in portions of $70 \mathrm{~g}$ of plant with $2 \times 500 \mathrm{~mL}$ each using an ultrasonic bath to yield $12.19 \mathrm{~g}$ of material. This extract was chromatographed in a column $(250 \mathrm{~mm} \times 60 \mathrm{~mm}$ i.d., $300 \mathrm{~g}$ of silica gel 60A) using hexane/acetone mixtures of increasing polarity from 0 to $100 \%$ in acetone increasing $10 \%$ each time and finishing with $100 \%$ methanol ( $500 \mathrm{~mL}$ of each polarity) to afford 11 fractions: A-L. These fractions were bioassayed with etiolated wheat coleoptiles and the most bioactive fractions were assayed for phytotoxicity on standard target species.

Fractions D, E, F, and G showed bioactivity in the wheat coleoptile bioassay and these were rechromatographed. Fraction D (hexane/ acetone, $70: 30 \mathrm{v} / \mathrm{v}, 512 \mathrm{mg}$ ) was subjected to chromatographic column $(250 \mathrm{~mm} \times 40 \mathrm{~mm}$ i.d., $175 \mathrm{gr}$ of silica gel $60 \mathrm{~A})$ using hexane/ acetone mixtures of increasing polarity from 20 to $100 \%$ in acetone, increasing $10 \%$ each time and finishing with $100 \%$ methanol $(250 \mathrm{~mL}$ of each polarity) to afford 8 fractions (D1-D8). Fraction D4 (144 mg, $5 \mathrm{mg} /$ injection) was purified by HPLC (RP-18 semipreparative column) using water/acetone $(40: 60 \mathrm{v} / \mathrm{v}$, flow $3 \mathrm{~mL} / \mathrm{min})$ to yield 1 $(23 \mathrm{mg}$, retention time $11 \mathrm{~min})$. Fraction D5 $(155 \mathrm{mg})$ was subjected to chromatographic column $(200 \mathrm{~mm} \times 30 \mathrm{~mm}$ i.d., $60 \mathrm{gr}$ of silica gel $60 \mathrm{~A}$ ) using dichloromethane/acetone mixtures of increasing polarity from 30 to $100 \%$ in acetone increasing $10 \%$ each time and finishing with $100 \%$ methanol $(150 \mathrm{~mL}$ of each polarity) to afford 4 fractions (D5.1-D5.4). Fraction D5.1 (55 mg, $5 \mathrm{mg} /$ injection) was purified by HPLC (RP-18 semipreparative column) using water/acetone (45:55 $\mathrm{v} / \mathrm{v}$, flow $3 \mathrm{~mL} / \mathrm{min})$ to yield $2(7.1 \mathrm{mg}$, retention time $6 \mathrm{~min})$ and a second peak (retention time $7 \mathrm{~min}$ ). This peak was further purified by HPLC using water/acetone $(70: 30 \mathrm{v} / \mathrm{v}$, flow $1 \mathrm{~mL} / \mathrm{min}, 0.5 \mathrm{mg} /$ injection, RP-18 analytical column) to yield $3(0.7 \mathrm{mg}$, retention time $19 \mathrm{~min}$ ).Fraction E (hexane/acetone, 50:50 v/v, $301 \mathrm{mg}$ ) was subjected to chromatographic column $(200 \mathrm{~mm} \times 40 \mathrm{~mm}$ i.d., 140 $\mathrm{g}$ silica gel 60A) using dichloromethane/acetone mixtures of increasing polarity from 20 to $100 \%$ in acetone increasing $10 \%$ each time and finishing with $100 \%$ methanol ( $200 \mathrm{~mL}$ of each polarity) to afford 3 fractions (E1, E2, and E3). Fraction E1+E2 (146 mg) was subjected to a chromatographic column $(60 \times 95 \mathrm{~mm}$ i.d., $200 \mathrm{~g}$ of silica gel RP-18) using water/methanol mixtures from 10 to $100 \%$ in methanol increasing $10 \%$ each time $(150 \mathrm{~mL}$ of each polarity) to afford four fractions (E1.1-E1.4). Fraction E1.1 (84 mg, $5 \mathrm{mg} /$ injection) was purified by HPLC (RP-18 semipreparative column) using water/ acetone $(45: 55 \mathrm{v} / \mathrm{v}$, flow $3 \mathrm{~mL} / \mathrm{min})$ to yield $2(10 \mathrm{mg}$, retention time $6 \mathrm{~min}$ ) and a second peak (retention time $7.9 \mathrm{~min}$ ). This peak was further purified by HPLC using water/acetone $(75: 25 \mathrm{v} / \mathrm{v}$, flow $1 \mathrm{~mL} /$ $\mathrm{min}, 0,5 \mathrm{mg} /$ injection, RP-18 analytical column) to yield $4(1.5 \mathrm{mg}$, retention time $18.7 \mathrm{~min}$ ). Fraction F was mainly composed of 5 (241 $\mathrm{mg}$ ). Fraction G (hexane/acetone, 40:60 v/v, $352 \mathrm{mg}$ ) was subjected to chromatographic column $(200 \times 40$ i.d., $140 \mathrm{~g}$ silica gel $60 \mathrm{~A})$ using dichloromethane/acetone mixtures of increasing polarity from 40 to $100 \%$ in acetone increasing $10 \%$ and finishing with $100 \%$ methanol (200 $\mathrm{mL}$ of each polarity) to afford 3 fractions (G1-G3). Fraction G2 (145 mg, $5 \mathrm{mg} /$ injection) was purified by HPLC (RP-18 semipreparative column) using water/acetone $(40: 60 \mathrm{v} / \mathrm{v}$, flow $3 \mathrm{~mL} / \mathrm{min})$ to yield 6 (36 mg, retention time $9 \mathrm{~min})$.

Coleoptile Bioassay. Wheat seeds (Triticum aestivum L. cv. Duro) were sown in $15 \mathrm{~cm}$ diameter Petri dishes moistened with water and grown in the dark at $25 \pm 1{ }^{\circ} \mathrm{C}$ for 4 days. ${ }^{29}$ The roots and caryopses were removed from the shoots. The latter were placed in a Van der Weij guillotine and the apical $2 \mathrm{~mm}$ were cut off and discarded. The next $4 \mathrm{~mm}$ of the coleoptiles were removed and used for bioassays. All manipulations were performed under a green safelight. ${ }^{30}$ Crude extracts, fractions or pure compounds were predissolved in dimethyl sulfoxide $(0.1 \%)$ and diluted in phosphate-citrate buffer containing $2 \%$ sucrose $^{30}$ at $\mathrm{pH} 5.6$ to the final bioassay concentrations $(0.8,0.4$, and 


\section{Lactuca sativa}

Germination Shoot length Root length

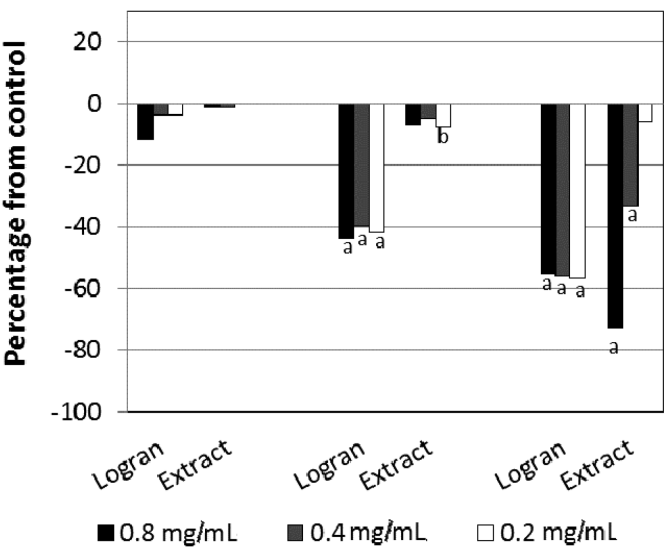

Lycopersicon esculentum

Germination Shoot length Root length

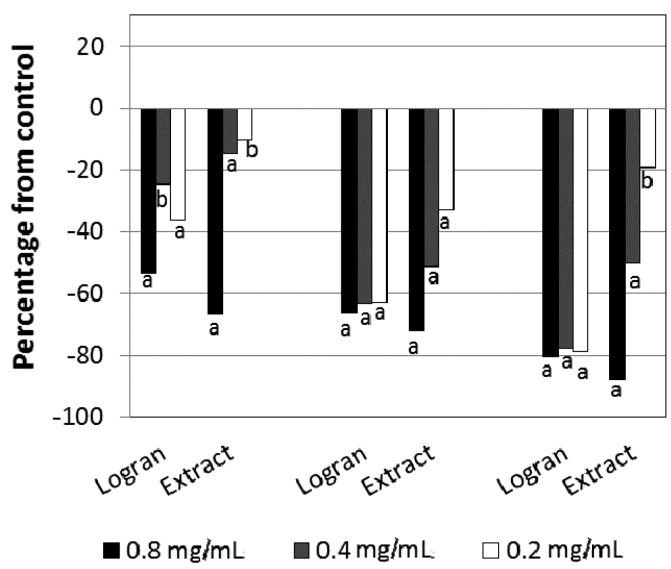

Lepidium sativum

Germination Shoot length Root length

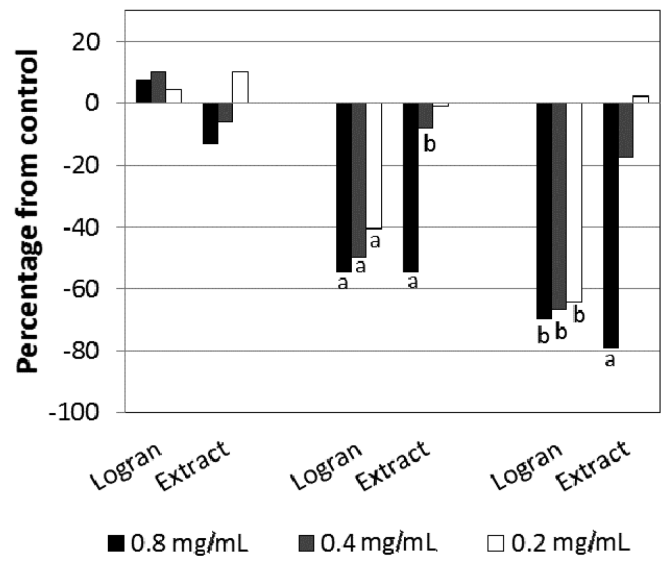

Allium cepa

Germination Shoot length Root length

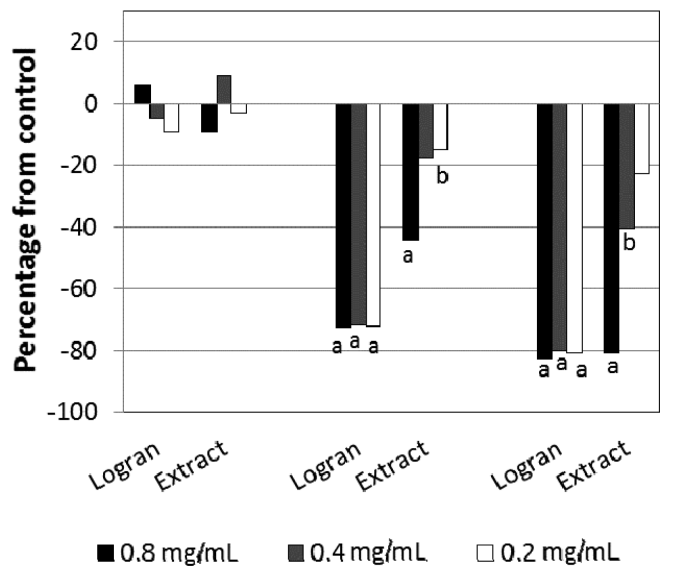

Figure 1. Effects of the herbicide Logran and ethyl acetate (EtOAc) leaf extract of cardoon (Cynara cardunculus) on standard target species growth. Values are expressed as percentage difference from control.

$0.2 \mathrm{mg} / \mathrm{mL}$ for extracts and fractions, and $10^{-3}, 3 \times 10^{-4}, 10^{-4}, 3 \times$ $10^{-5}$, and $10^{-5} \mathrm{M}$ for compounds).

Parallel controls were also run. The commercial herbicide Logran, whose original formulation is a combination of $N^{2}$-tert-butyl- $N^{4}$-ethyl6-(methylsulfanyl)-1,3,5-triazine-2,4-diamine (terbutryn, 59.4\%) and 2-(2-chloroethoxy)- $N$-[(4-methoxy-6-methyl-1,3,5-triazin-2-yl)carbamoyl] benzene-1-sulfonamide (triasulfuron, $0.6 \%$ ), was used as positive control according to a comparison study reported previously. ${ }^{31}$ This reference was used at the same concentrations and under the same conditions as reported previously. Control samples (buffered aqueous solutions with dimethyl sulfoxide and without any test compound) were used for all of the plant species assayed.

Each assay was carried out in duplicate. Five coleoptiles and $2 \mathrm{~mL}$ of solution were placed in each test tube (three tubes per dilution) and the tubes were rotated at $0.25 \mathrm{rpm}$ in a roller tube apparatus for $24 \mathrm{~h}$ at $25{ }^{\circ} \mathrm{C}$ in the dark. The coleoptiles were measured by digitalization of their images. Data were statistically analyzed using Welch's test. ${ }^{32}$ Data are presented as percentage differences from control. Thus, zero represents the control, positive values represent stimulation of the studied parameter, and negative values represent inhibition.

Phytotoxicity Bioassays. The selection of target plants was based on an optimization process carried out in our search for a standard phytotoxicity bioassay. ${ }^{31}$ Several Standard Target Species were proposed, including the monocotyledon onion (Allium cepa L.) and the dicotyledons tomato (Lycopersicon esculentum Will.), cress (Lepidium sativum L.), and lettuce (Lactuca sativa L.), which were assayed for this study. In addition, two weed species were added as target plants in this bioassay: the monocotyledon barnyardgrass ( $E$. crus-galli L.) and the dicotyledon brachiaria (Urochloa decumbens (Stapf) R.D. Webster).

Bioassays were conducted using Petri dishes $(50 \mathrm{~mm}$ diameter) with one sheet of Whatman No. 1 filter paper as a support. Germination and growth were conducted in aqueous solutions at controlled $\mathrm{pH}$ by using $10^{-2} \mathrm{M} 2$-[ $\mathrm{N}$-morpholino]ethanesulfonic acid (MES) and $1 \mathrm{M} \mathrm{NaOH}$ (pH 6.0). The extracts, fractions or compounds to be assayed were dissolved in dimethyl sulfoxide and these solutions were diluted with buffer ( $5 \mu \mathrm{L}$ dimethyl sulfoxide solution $/ \mathrm{mL}$ buffer) so that test concentrations for each extract or fraction $(0.8,0.4$, and $0.2 \mathrm{mg} / \mathrm{mL})$ and compound $\left(10^{-3}, 3 \times 10^{-4}\right.$, $10^{-4}, 3 \times 10^{-5}$, and $\left.10^{-5} \mathrm{M}\right)$ were achieved. Parallel controls were also run as described before for coleoptile bioassays.

Four replicates were used for tomato, cress, onion, and lettuce, each containing 20 seeds. Treatment, control or internal reference solution $(1 \mathrm{~mL})$ was added to each Petri dish. After adding the seeds and aqueous solutions, Petri dishes were sealed with Parafilm to ensure 
Urochloa decumbens Germination Shoot length Root length

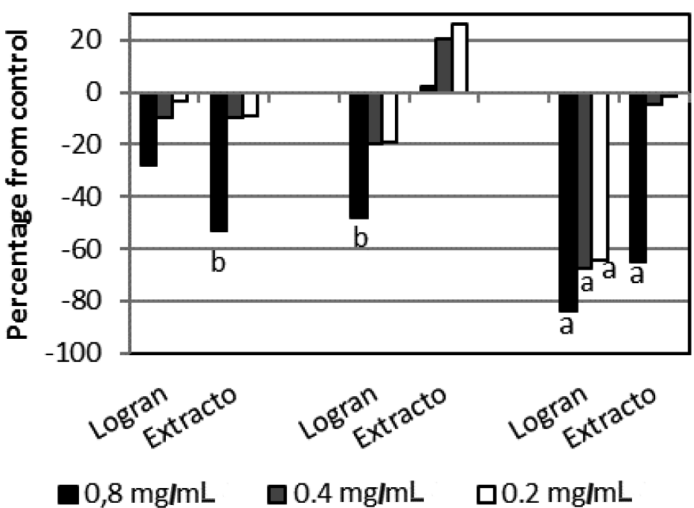

Echinochloa crus-galli

\section{Germination Shoot length Root length}

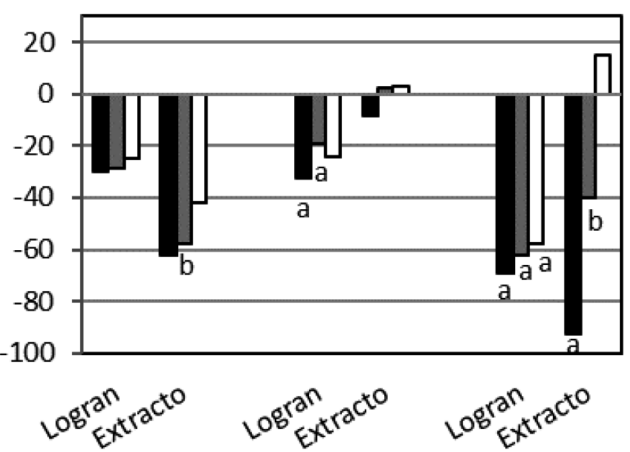

$0,8 \mathrm{mg} / \mathrm{mL} \quad \square 0.4 \mathrm{mg} / \mathrm{mL} \quad \square 0.2 \mathrm{mg} / \mathrm{mL}$

Figure 2. Effects of the herbicide Logran and ethyl acetate (EtOAc) leaf extract of cardoon (Cynara cardunculus) on weed growth. Values are expressed as percentage difference from control.<smiles>C=C(C)C(=O)OC1CC(=C)[C@H]2CC(O)C(=C)[C@H]2[C@H]1OC(=O)C(=C)C</smiles>

aguerin B<smiles>C=C1C(=O)O[C@@H]2[C@H]1CC(=C)[C@H]1OC(=O)C(=C)[C@H]2[C@H]1OC(C)=O</smiles>

$8 \alpha$-acetoxyzaluzanin C<smiles>C=CC1(C)C[C@H](O)[C@H]2C(=C)C(=O)O[C@H]2C1C(=C)CO</smiles>

dehydromelitensin<smiles>C=C(CO)C(=O)OC1CC(=C)[C@H]2CC(O)C(=C)[C@H]2C1C(=C)C(=O)O</smiles>

cynaropicrin

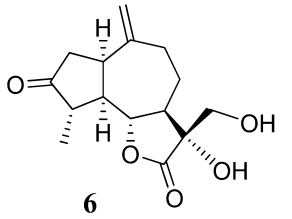

11,13-dihydroxi-8desoxigrosheimin

Figure 3. Compounds isolated from cardoon (Cynara cardunculus). Aguerin B, 1, grosheimin, 2, $8 \alpha$-acetoxyzaluzanin C, 3, and dehydromelitensin, 4, cynaropicrin, 5, and 11,13-dihydroxy-8-desoxygrosheimin, 6.

closed-system models. Seeds were further incubated at $25{ }^{\circ} \mathrm{C}$ in a Memmert ICE 700 controlled environment growth chamber. The photoperiod was $24 \mathrm{~h}$ of dark for onion, tomato, cress, and lettuce, and $16 / 8 \mathrm{~h}$ light/dark for barnyardgrass and brachiaria. Bioassays took 4 days for cress, 5 days for tomato, 6 days for lettuce, 7 days for onion, and 8 days for barnyardgrass and brachiaria. After growth, plants were frozen at $-10{ }^{\circ} \mathrm{C}$ for $24 \mathrm{~h}$ to avoid subsequent growth during the measurement process.

Evaluated parameters (germination rate, root length, and shoot length) were recorded using a Fitomed system, ${ }^{33}$ which allowed automatic data acquisition and statistical analysis using its associated software. Data were analyzed statistically using Welch's test, with significance fixed at 0.01 and 0.05 . Results are presented as percentage differences from the control. Zero represents control, positive values represent stimulation, and negative values represent inhibition.

\section{RESULTS AND DISCUSSION}

Dried leaves of cardoon (55 g) defatted with hexane were extracted with dichloromethane (dichloromethane, 0.33\% yield), ethyl acetate (ethyl acetate, $0.55 \%$ yield), acetone (acetone, $0.82 \%$ yield), and methanol (methanol, $0.89 \%$ yield), and then with distilled water (water, $2.98 \%$ yield). The extracts were tested in the etiolated wheat coleoptile bioassay. ${ }^{31}$ This is a rapid test that is sensitive to a wide range of bioactive substances $^{34}$ including plant growth regulators, herbicides, antimicrobials, mycotoxins, and assorted pharmaceuticals.

The extracts that showed the highest inhibition levels in the coleoptile bioassay were those extracted with dichloromethane, ethyl acetate, and acetone, which showed the highest inhibition values (around 90\%) at $0.8 \mathrm{mg} / \mathrm{mL}$. The methanol and water extracts showed lower inhibitory activity $(77 \%$ and $58 \%$ at 0.8 $\mathrm{mg} / \mathrm{mL}$, respectively). The dichloromethane and ethyl acetate extracts retained high activity levels at lower concentrations. Thus, the inhibition of these extracts at 0.4 and $0.2 \mathrm{mg} / \mathrm{mL}$ were dichloromethane 90 and $75 \%$, respectively, and ethyl acetate 87 and 69\%, respectively.

Although dichloromethane and ethyl acetate extracts showed almost the same activity values, the ethyl acetate extract was selected for further study because the yield was higher. As a result, the ethyl acetate extract was evaluated in the phytotoxicity assay (Figures 1 and 2). The concentrations tested in this bioassay were identical to those described previously. The standard target species were lettuce, tomato, cress, and onion ${ }^{31}$ (Figure 1) and the weed species were barnyardgrass and brachiaria (Figure 2).

The parameter that was most markedly affected by the extract was root length (Figures 1 and 2). The inhibition shown 
by the extract was higher than or equal to that of Logran at 0.8 $\mathrm{mg} / \mathrm{mL}$ on both standard target species and weeds roots, with values close to $80 \%$ inhibition in most species. The extract was also active on the germination of tomato, brachiaria, and barnyardgrass, and on the shoot length of cress, tomato, onion, and barnyardgrass.

These results clearly show that the extract obtained from cardoon has phytotoxic activity not only on standard target species plants but also on important weed species. Therefore, it was decided to isolate and identify the constituent compounds and study their bioactivity in an effort to understand the invasive behavior of the plant and to discover new tools for weed control.

The ethyl acetate extract was chromatographed on silica gel using hexane/acetone mixtures of increasing polarity to afford fractions $A$ to $L$. These fractions were used in etiolated wheat coleoptile bioassays to biodirect the purification of the allelochemicals. The most active fractions were those with intermediate polarities, that is, fractions $D, E, F$, and G. In particular, fractions $\mathrm{D}, \mathrm{F}$ and $\mathrm{G}$ presented inhibition values close to $100 \%$ at $0.8 \mathrm{mg} / \mathrm{mL}$.

The chromatographic separation of fractions D, E, F, and G allowed us to isolate six sesquiterpene lactones. The isolated compounds were identified by their spectroscopic data $\left({ }^{1} \mathrm{H}\right.$ NMR, ${ }^{13} \mathrm{C}$ NMR, HMQC, COSY, HMBC, IR, and MS) in comparison to those reported in the literature for aguerin $\mathrm{B},{ }^{35}$ 1, grosheimin, ${ }^{36} 2,8 \alpha$-acetoxyzaluzanin $C,{ }^{35} 3$ dehydromelitensin, ${ }^{37} 4$, cynaropicrin, ${ }^{35} \mathbf{5}$ and 11,13-dihydroxy-8-deoxygrosheimin, ${ }^{38}$ 6. (Figure 3). Sesquiterpenic lactones are characteristic of Asteraceae. ${ }^{39}$ Metabolites $\mathbf{2}$ and $\mathbf{5}$ have been reported recently from cardoon extracts ${ }^{40}$ whereas compounds 1, 3, 4 and 6 are reported for the first time from this species.

The bioactivities of compounds 1, 2, 5, and 6 were assessed in a wheat coleoptile bioassay from $10^{-3} \mathrm{M}$ to $10^{-5} \mathrm{M}$. Compounds 3 and 4 were not tested because insufficient sample was available (less than $1 \mathrm{mg}$ ). Compounds 1 , 2, and 5 showed high inhibitory activity on the coleoptile elongation, with almost $90 \%$ activity at $10^{-3} \mathrm{M}$ (Figure 4). Compounds $\mathbf{1}$, 2 , and 5 were also active at the second concentration $\left(3.10^{-4}\right.$ M) (70, 75 and 55\% inhibition, respectively) and their activity decreased from a concentration of $10^{-4} \mathrm{M}$ and below.

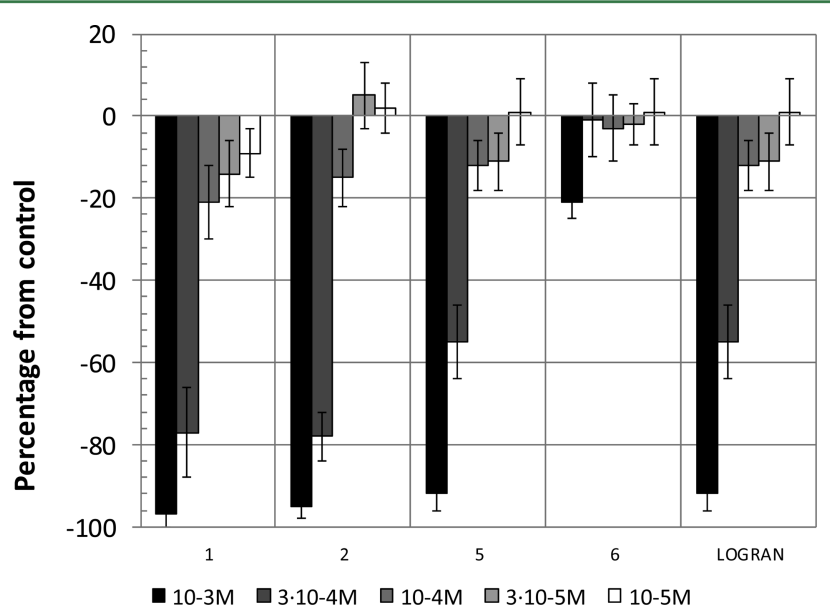

Figure 4. Effects of compounds aguerin B, 1, grosheimin, 2, cynaropicrin, 5, and 11,13-dihydroxy-8-desoxygrosheimin, 6, from cardoon (Cynara cardunculus) on the elongation of etiolated wheat coleoptiles.
Since compounds $\mathbf{1}, \mathbf{2}$, and $\mathbf{5}$ were very active in the coleoptile bioassay, their phytotoxicity was also tested on standard target species (Figure 5) development. Germination was the least affected parameter, although the compounds were much more active at $10^{-3} \mathrm{M}$ on cress and tomato than the reference herbicide. Indeed, inhibition reached levels of almost $90 \%$ on tomato germination.

Shoot length was only affected by compounds at the highest concentration and, in most cases, the inhibition levels were higher than those of the reference herbicide, with values close to $70 \%$ in the cases of $\mathbf{5}$ on lettuce and $\mathbf{1}$ and $\mathbf{5}$ on cress and tomato (Figure 5).

Root length was the variable that was most affected by the allelochemicals, mainly at the first concentration $\left(10^{-3} \mathrm{M}\right)$ but also at the second one $\left(3 \cdot 10^{-4} \mathrm{M}\right)$. As for other parameters, the compounds were more phytotoxic than the reference herbicide in most cases. Compounds 1, 2, and $\mathbf{5}$ were very active (from 70 to $90 \%$ inhibition) on root length of cress and tomato. Compounds $\mathbf{2}$ and $\mathbf{5}$ also showed activity on onion root length.

In view of the results described above, compounds $\mathbf{1}, \mathbf{2}$, and 5 were also tested on the weeds barnyardgrass and brachiaria with a photoperiod of $16 / 8 \mathrm{~h}$ light/dark (Figure 6). Germination was once again the parameter that was least affected and the compounds were more active at $10^{-3} \mathrm{M}$ on brachiaria than the reference herbicide, with inhibition of $90 \%$ on brachiaria. Shoot length was not affected by any of the compounds with the exception of $\mathbf{2}$ on brachiaria at the highest concentration, which gave a value close to $80 \%$ inhibition.

As for the standard target species species, root length was the parameter that was most markedly affected by the allelochemicals, mainly at the first concentration $\left(10^{-3} \mathrm{M}\right)$. All compounds were more active than the reference herbicide (from 70 to $90 \%$ ) on the root length of the two weeds barnyardgrass and brachiaria.

The extracts, fractions and compounds showed similar activity profiles in the wheat coleoptile and seedling bioassays (Figure 1, 2, 4, 5, and 6) and this indicates that the bioactivity of the extracts and fractions can be explained by the presence of the compounds identified.

The analysis of compounds 1, 2, 5, and 6 enabled some observations to be made concerning the relationship between their structure and activity, considering the structures of the molecules and the differences between them. The absence of activity in 6 could be explained by the absence of an $\alpha$ methylene group, which is present in the other compounds. Changes in the lateral chain or oxidation pattern at C-3 in 1, 2, and $\mathbf{5}$ seems to have little influence on the activity.

As observed in the phytotoxicity bioassay on the extracts (Figures 1 and 2), compounds 1, 2, and 5 were active not only on standard target species but also on the very important weeds (Figures 5 and 6). Other guaianolide sesquiterpene lactones have been reported to be cytotoxic, ${ }^{41}$ fungicidal, ${ }^{42}$ antiviral, and antimicrobial. ${ }^{43}$ Allelopathic activity has also been described. ${ }^{44-46}$ The amounts in which these compounds are biosynthesized and their wide spectrum of biological activity, including phytotoxicity, suggest that they may be involved in the defense mechanism of this species. This variety of biological activities supports the "economy of resources" principle, which states that a defense metabolite is cheaper in terms of resource investment if it can serve more than one purpose. Allelopathy, a general defense mechanism present in plants, can involve these metabolites. $^{47}$ 
Lactuca sativa

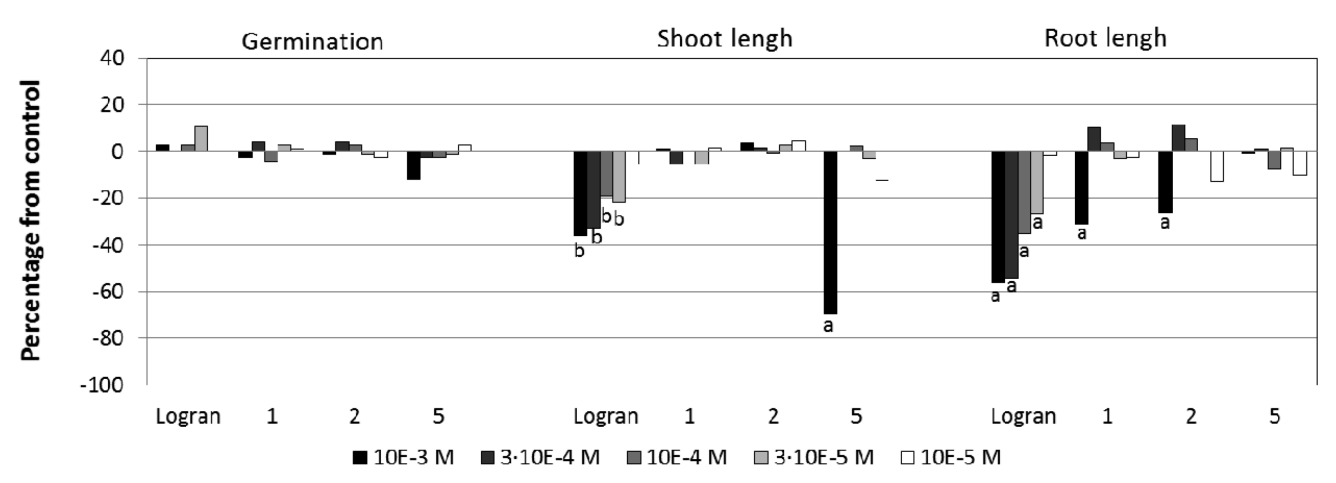

Lepidium sativum

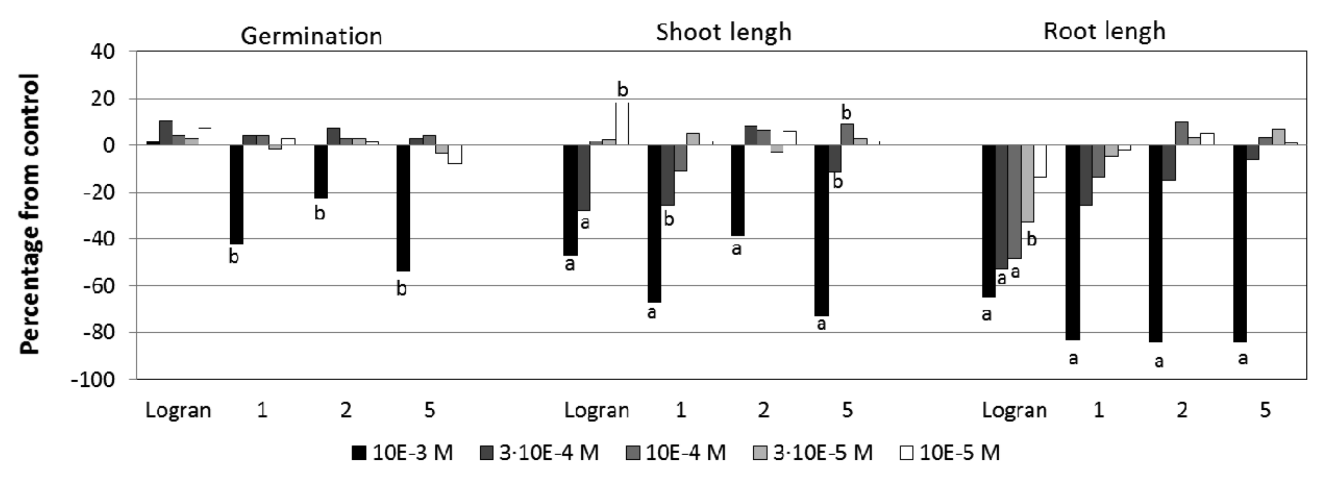

Lycopersicon esculentum

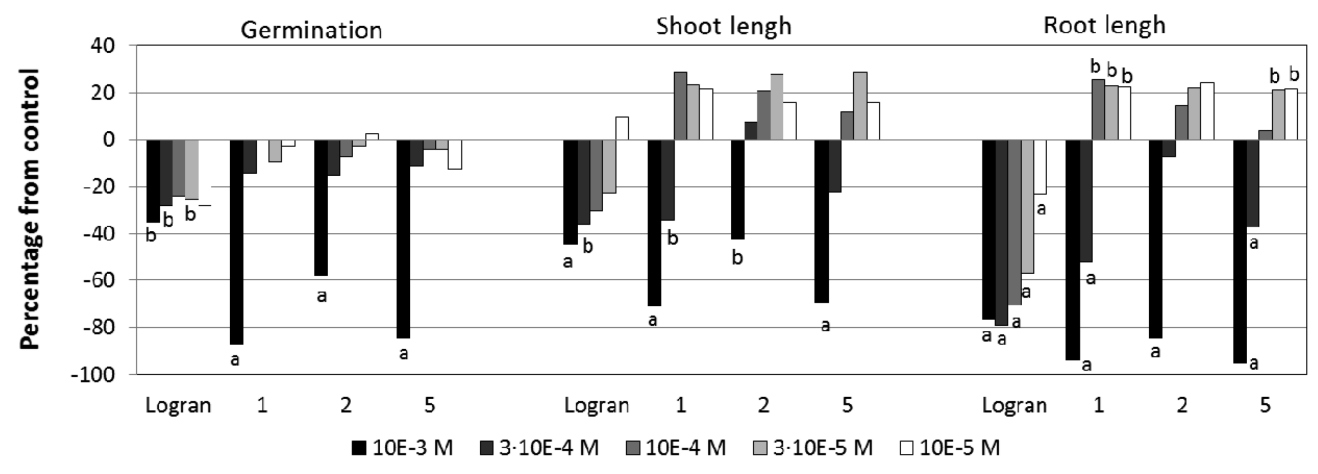

Allium cepa

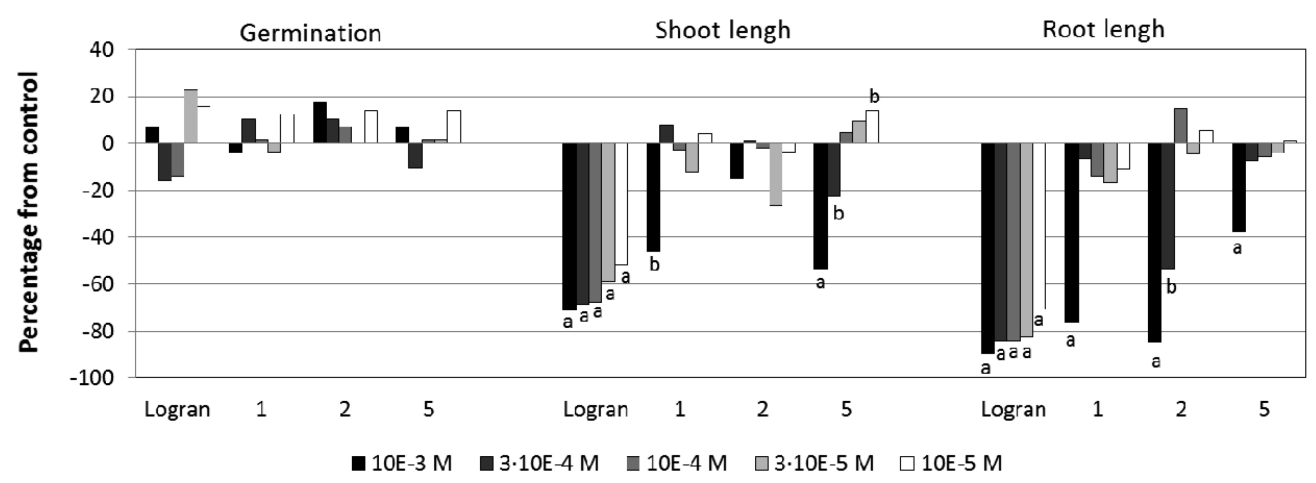

Figure 5. Effects of compounds aguerin B, 1, grosheimin, 2, and cynaropicrin, 5, from cardoon (Cynara cardunculus) on standard target species growth. Values are expressed as percentage difference from control.

The strong phytotoxicity shown by the extracts and the pure major compounds aguerin B, 1, grosheimin, 2, and cynaropicrin, 5, on the important weeds brachiaria and barnyardgrass demonstrates the strong potential of C. cardunculus for use in the biological control of weeds. This species could be used as a plant applied as a cover crop, as 
Urochloa decubems

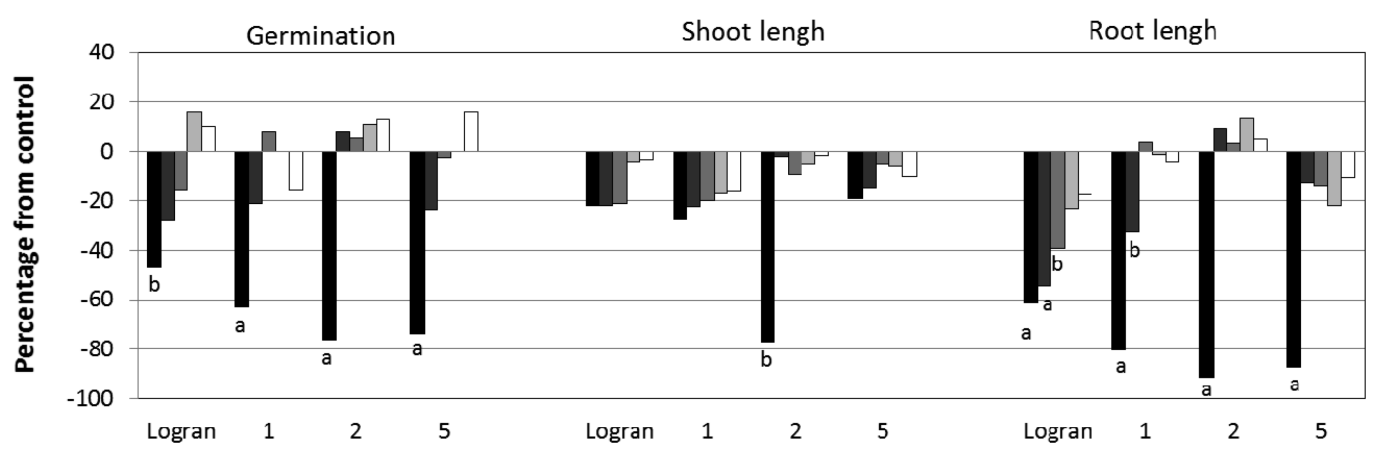

Echinochloa crus-galli

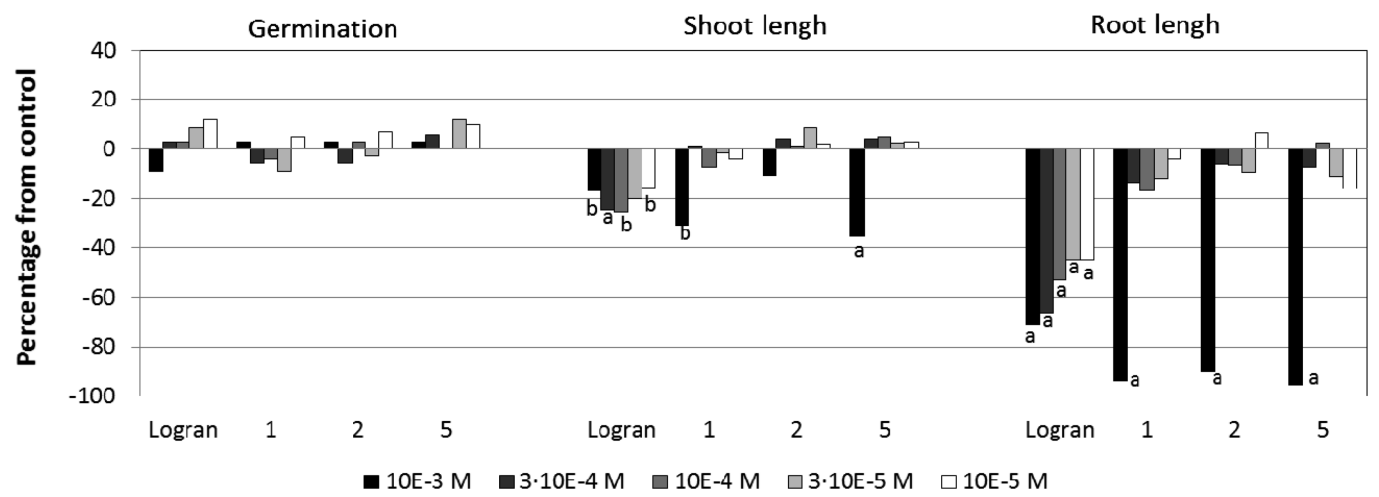

Figure 6. Effects of compounds aguerin B, 1, grosheimin, 2, cynaropicrin, 5, from cardoon (Cynara cardunculus) on weed growth. Values are expressed as percentage difference from control.

mulching and plant extracts or as a source of natural herbicide models.

\section{AUTHOR INFORMATION}

\section{Corresponding Author}

*Tel: +34 956.012.770. Fax: +34 956.016.193. Email: famacias@uca.es.

Notes

The authors declare no competing financial interest.

\section{ACKNOWLEDGMENTS}

This research was supported by the $\mathrm{CNPq}$ (Conselho Nacional de Pesquisa), Brazil, the Ministerio de Educación y Ciencia (Project No. AGL2009-08864 (AGR), and Junta de Andalucía (PAI-III, AGR-5822), Seville, Spain.

\section{REFERENCES}

(1) Pimentel, D.; Zuniga, R.; Morrison, D. Update on the environmental and economic costs associated with alien-invasive species in the United States. Ecol. Econ. 2005, 52, 273-288.

(2) van Kleunen, M.; Weber, E.; Fischer, M. A meta-analysis of trait differences between invasive and non-invasive plant species. Ecol. Lett. 2010, 13, 235-245.

(3) Mack, R. N.; Simberloff, D.; Lonsdale, W. M.; Evans, H.; Clout, M.; Bazzaz, F. A. Biotic invasions: Causes, epidemiology, global consequences, and control. Ecol. Appl. 2000, 10, 689-710.

(4) Rice, E. L. Allelopathy; Academic Press: New York, NY, 1984.

(5) Chou, C. H. Roles of allelopathy in plant biodiversity and sustainable agriculture. Crit. Rev. Plant Sci. 1999, 18, 609-636.

(6) Hagan, D. L.; Jose, S.; Lin, C. H. Allelopathic exudates of cogongrass (Imperata cylindrica): Implications for the performance of native pine savanna plant species in the southeastern U.S. J. Chem. Ecol. 2013, 39, 312-322.

(7) Sardans, J.; Llusia, J.; Niinemets, U.; Owen, S.; Penuelas, J. Foliar mono- and sesquiterpene contents in relation to leaf economic spectrum in native and alien species in Oahu (Hawaii). J. Chem. Ecol. 2010, 36, 210-226.

(8) Weidenhamer, J. D.; Callaway, R. M. Direct and indirect effects of invasive plants on soil chemistry and ecosystem function. J. Chem. Ecol. 2010, 36, 59-69.

(9) Vyvyan, J. R. Allelochemicals as leads for new herbicides and agrochemicals. Tetrahedron 2002, 58, 1631-1646.

(10) Macías, F.; Oliveros-Bastidas, A.; Marín, D.; Carrera, C.; Chinchilla, N.; Molinillo, J. G. Plant biocommunicators: Their phytotoxicity, degradation studies, and potential use as herbicide models. Phytochem. Rev. 2008, 7, 179-194.

(11) Pignone, D.; Sonnante, G. Wild artichokes of south Italy: Did the story begin here? Genet. Resour. Crop Ev. 2004, 51, 577-580.

(12) White, V. A. Environmental physiology of an invasive weed, Cynara cardunculus. University of California Press, Riverside, CA, 2004.

(13) Marushia, R. G.; Holt, J. S. Reproductive strategy of an invasive thistle: Effects of adults on seedling survival. Biol. Invasions 2008, 10, 913-924.

(14) White, V. A.; Holt, J. S. Competition of artichoke thistle (Cynara cardunculus) with native and exotic grassland species. Weed Sci. 2005, 53, 826-833.

(15) Prados, F.; Pino, A.; Fernández-Salguero, J. Effect of a powdered vegetable coagulant from cardoon Cynara cardunculus in the accelerated ripening of Manchego cheese. Int. J. Food Sci. Technol. 2007, 42, 556-561.

(16) Valentao, P.; Fernandes, E.; Carvalho, F.; Andrade, P. B.; Seabra, R. M.; Bastos, M. L. Antioxidative properties of cardoon (Cynara 
cardunculus L.) infusion against superoxide radical, hydroxyl radical, and hypochlorous acid. J. Agric. Food Chem. 2002, 50, 4989-4993.

(17) Velez, Z.; Campinho, M.; Guerra, Â.; García, L.; Ramos, P.; Guerreiro, O.; Felício, L.; Schmitt, F.; Duarte, M. Biological characterization of Cynara cardunculus L. methanolic extracts: Antioxidant, anti-proliferative, anti-migratory, and anti-angiogenic activities. Agriculture 2012, 2, 472-492.

(18) Kukic, J.; Popovic, V.; Petrovic, S.; Mucaji, P.; Ciric, A.; Stoikovic, D.; Sokovic, M. Antioxidant and antimicrobial activity of Cynara cardunculus extracts. Food Chem. 2008, 107, 861-868.

(19) Fratianni, F.; Tucci, M.; De Palma, M.; Pepe, R.; Nazzaro, F. Polyphenolic composition in different parts of some cultivars of globe artichoke (Cynara cardunculus L. var. scolymus (L.) Fiori). Food Chem. 2007, 104, 1282-1286.

(20) Slanina, J.; Paulova, H.; Humpa, O.; Bochorakova, H.; Taborska, E. 1,5-dicaffeoylquinic acid, an antioxidant component of Cynara cardunculus leaves. Scr. Med. Fac. Med. Univ. Brun. Masaryk. 1999, 72, 9-17.

(21) Mucaji, P.; Grancai, D.; Nagy, M.; Visnovská, Z.; Ubik, K. Apigenin-7-methylglucuronide from Cynara cardunculus L. Ces. Slov Farm. 2000, 49, 75-77.

(22) Talbert, R. E.; Burgos, N. R. History and management of herbicide-resistant barnyardgrass (Echinochloa crus-galli) in Arkansas rice. Weed Technol. 2007, 21, 324-331.

(23) Mitich, L. W. Index for "Intriguing world of weeds". Weed Technol. 1991, 5, 916-918.

(24) Holm, L. G.; Plucknett, D. L.; Pancho, J. V.; Herberger, J. P. The World'S Worst Weeds: Distribution and Biology; University Press of Hawaii: Honolulu, HI, 1977.

(25) Souza, L. S.; Losasso, P. H. L.; Oshiiwa, M.; Garcia, R. R.; Goes Filho, L. A. Effects of Brachiaria decumbens control bands on the initial development and productivity of Coffea arabica. Planta Daninha 2006, 24, 715-720.

(26) Williams, D.; Baruch, Z. African grass invasion in the Americas: Ecosystem consequences and the role of ecophysiology. Biol. Invasions 2000, 2, 123-140.

(27) D’Antonio, C. M.; Vitousek, P. M. Biological invasions by exotic grasses, the grass/fire cycle, and global change. Annu. Rev. Ecol. Evol. Syst. 1992, 23, 63-87.

(28) Raccuia, S. A.; Melilli, M. G. Seasonal dynamics of biomass, inulin, and watersoluble sugars in roots of Cynara cardunculus L. Field Crop Res. 2010, 116, 147-153.

(29) Hancock, C.; Barlow, H.; Lacey, H. The east malling coleoptile straight growth test method. J. Exp. Bot. 1964, 15, 166-176.

(30) Nitsch, J. P.; Nitsch, C. Studies on the growth of coleoptile and first internode sections. A new, sensitive, straight-growth test for auxins. Plant Physiol. 1956, 31, 94-111.

(31) Macias, F. A.; Castellano, D.; Molinillo, J. M. G. Search for a standard phytotoxic bioassay for allelochemicals. Selection of standard target species. J. Agric. Food Chem. 2000, 48, 2512-2521.

(32) Martín, A.; Luna, J. d. D. Bioestadistica para las ciencias de la salud; Ediciones Norma: Madrid, Spain, 1990.

(33) Castellano, D. Optimización de bioensayos alelopáticos. Aplicación en la búsqueda de herbicidas naturales. $\mathrm{PhD}$ dissertation, Universidad de Cádiz, Spain, 2002.

(34) Cutler, S. J.; Hoagland, R. E.; Cutler, H. G. Evaluation of selected pharmaceuticals as potential herbicides: bridging the gap between agrochemicals and pharmaceuticals. In Allelopathy in Ecological Agriculture and Forestry; Narwal, S. S.; Hoagland, R. E.; Dilday, R. H.; Reigosa, R. M. J., Eds.; Springer: New York, 2000; pp 129-137.

(35) Ha, T. J.; Jang, D. S.; Lee, J. R.; Lee, K. D.; Lee, J.; Hwang, S. W.; Jung, H. J.; Nam, S. H.; Park, K. H.; Yang, M. S. Cytotoxic effects of sesquiterpene lactones from the flowers of Hemisteptia lyrata B. Arch. Pharm. Res. 2003, 26, 925-928.

(36) Chen, W.; Liu, Q.; Wang, J.; Zou, J.; Meng, D.; Zuo, J.; Zhu, X.; Zhao, W. New guaiane, megastigmane, and eudesmane-type sesquiterpenoids and anti-inflammatory constituents from Youngia japonica. Planta Med. 2006, 72, 143-150.
(37) Cardona, M. L.; Garcia, B.; Pedro, J. R.; Sinisterra, J. F. Sesquiterpene lactones and an elemane derivative from Onopordon corymbosum. Phytochemistry 1989, 28, 1264-1267.

(38) Medjroubi, K.; Benayachel, F.; Leon, F.; Bermejo, J. Complete assignement of the ${ }^{13} \mathrm{C}$ and ${ }^{1} \mathrm{H}$ NMR spectra of two known guayanolides isolated from Centaurea. Rev. Colomb. Quím. 2003, 2, $17-22$.

(39) Seaman, F. C. Sesquiterpene lactones as taxonomic characters in the Asteraceae. Bot. Rev. 1982, 48, 121-595.

(40) Ramos, P. A. B.; Guerra, A. R.; Guerreiro, O.; Freire, C. S. R.; Silva, A. M. S.; Duarte, M. F.; Silvestre, A. J. D. Lipophilic extracts of Cynara cardunculus L. var. altilis (DC): A source of valuable bioactive terpenic compounds. J. Agric. Food Chem. 2013, 61, 8420-8429.

(41) Muhammad, I.; Takamatsu, S.; Mossa, J. S.; El-Feraly, F. S.; Walker, L. A.; Clark, A. M. Cytotoxic sesquiterpene lactones from Centaurothamnus maximus and Vicoa pentanema. Phytother. Res. 2003, $17,168-173$.

(42) Wedge, D. E.; Galindo, J. C. G.; Macias, F. A. Fungicidal activity of natural and synthetic sesquiterpene lactone analogs. Phytochemistry 2000, 53, 747-757.

(43) Özçelik, B.; Gürbüz, I.; Karaoglu, T.; Yeşilada, E. Antiviral and antimicrobial activities of three sesquiterpene lactones from Centaurea solstitialis L. ssp. solstitialis. Microbiol. Res. 2009, 164, 545-552.

(44) de Luque, A. P.; Galindo, J. C. G.; Macias, F. A.; Jorrin, J. Sunflower sesquiterpene lactone models induce Orobanche cumana seed germination. Phytochemistry 2000, 53, 45-50.

(45) Macias, F. A.; Galindo, J. C. G.; Molinillo, J. M. G.; Castellano, D. Dehydrozaluzanin C: A potent plant growth regulator with potential use as a natural herbicide template. Phytochemistry 2000, 54, $165-171$.

(46) Macías, F. A.; Velasco, R. F.; Castellano, D.; Galindo, J. C. Application of Hansch's model to guaianolide ester derivatives: A quantitative structure-activity relationship study. J. Agric. Food Chem. 2005, 53, 3530-3539.

(47) Macías, F. A.; Molinillo, J. M. G.; Varela, R. M.; Galindo, J. C. G. Allelopathy-A natural alternative for weed control. Pest Manage. Sci. 2007, 63, 327-348. 